\title{
An Overview of the Language History of the Hungarian Jewish Community in the Carpathian Basin and Diaspora with a Special Emphasis on Yiddish
}

\section{Siarl Ferdinand ${ }^{*}$}

\begin{abstract}
This paper presents a brief language history of the Hungarian Jewish community since their establishment in the Carpathian Basin to the present, with a special focus on Yiddish. Between the Middle Ages and the nineteenth century, Yiddish became the group's majority language; after the 1850s, the Hungarian Jewry started a process of language substitution. By the 1930s, the use of Yiddish was mostly limited to the ultraOrthodox communities of Eastern Hungary, while the rest mainly adopted Hungarian. In this research, a pilot study of the current situation of Yiddish has been mapped using several methods, including a questionnaire answered by a hundred and thirty individuals and unstructured interviews with linguists. Although this study's results confirm the earlier research by Matras (2010) and Shandler (2006) in establishing that Yiddish is generally a post-vernacular language while Hungarian has acquired the role of an ethnic language, it was found that a considerable percentage of those living in the Carpathian Basin still preserve Yiddish. This paper aims to contribute to a more comprehensive understanding of the group dynamics in bilingual communities and, specifically, to provide a clearer view of the language situation among the Hungarian Jewry.
\end{abstract}

Keywords: Yiddish, Hungarian Jews, Language vitality, Jewish sociolinguistics, Hungary

Biography: Siarl Ferdinand is a Ph.D. candidate in Bilingual Studies at the University of Wales Trinity St David in Lampeter. He is currently teaching at the National University of Mongolia as a guest scholar, where he is also conducting research on the usage of the Mongolian language in Ulaanbaatar. His main research interests focus on topics related to minority languages and cultures from Europe and Central Asia, including language revitalization,

\footnotetext{
* I would like to express my deep gratitude to Flora Komlosi-Ferdinand for her help with translations, advice, encouragement and useful criticism of this research project. I would also like to thank Dr Noémi Vanderstein and Dr Balázs Fényes for the incredible amount of data and experiences they shared and their useful and constructive recommendations on this project. My grateful thanks are also extended to the American Hungarian Educators Association (AHEA) and the Budapest University of Jewish Studies for their assistance in contacting scholars and participants. I would also like to extend my thanks to all the survey participants for their willingness to share their experiences and distribute the questionnaire among family and friends.
} 
Ferdinand, Siarl. "An Overview of the Language History of the Hungarian Jewish Community in the Carpathian Basin and Diaspora with a Special Emphasis on Yiddish." Hungarian Cultural Studies. e-Journal of the American Hungarian Educators Association, Volume 13 (2020) DOI: 10.5195/ahea.2020.395

language maintenance, and language death. Beyond his scientific activity, he has published articles and short stories in Ladino (Judeo-Spanish), Catalan and Asturian. In this journal he has previously published the article, "Situation of the Csángó Dialect of Moldavia in Romania" http://dx.doi.org/10.5195/ahea.2016.231, and co-authored "The Use of Hungarian and Serbian in the City of Szabadka/Subotica: An Empirical Study"

http://dx.doi.org/10.5195/ahea.2017.278.yeth_kernewek@yahoo.co.uk

Despite its rather small population of over nine million, Hungary contains one of the largest Jewish populations in the world, the numbers of which range from approximately 50,000 individuals to an enlarged Jewish population encompassing those with some Jewish ancestry $(100,000$ to 150,000 individuals), many of whom are not aware of their background (Della Pergola 2010: 49; Spolsky 2014: 213). There are also Hungarian Jewish communities and individuals in all of Hungary's neighboring countries who were cut off from the core Hungarian Jewish community after 1919. In addition, an undetermined number of Hungarian Jews is spread throughout the world, with concentrations mostly in North America and Israel (Krogh 2018: 5-6; Simons \& Fennig 2018).

The history of the Jews in the Carpathian Basin can be traced back to the second century $\mathrm{CE}$, when soldiers from Palestine were sent to the Roman province of Dacia (CarmillyWeinberger 1995: 14). During the ninth century, along with the Magyars, there was an influx of Kabars, a group of semi-nomadic tribes whose leaders practiced a version of the Jewish religion (Golden 2007: 150). Around the year 1000, Hungary's Jewish population may have been very small, yet not insignificant: some contemporary documents mention both Jews living in "Hungarin" and Hungarian Jews trading in Prague (Patai 1996: 40; Spolsky 2014: 173; Weinreich 2008: A62). Despite the alteration of favorable and unfavorable times, the Jewish community continued growing (Patai 1996: 162-163, 182; Haraszti 1997: 38; Bányai 2013: 75). By the nineteenth century, Hungarian Jews accounted for approximately five percent of the Hungarian population and constituted a better-educated community within the Kingdom of Hungary (Patai 1996: 377; Volkov 2003: 223). However, due to legal obstacles and prejudices, it was not easy for any Jew to achieve a satisfactory social or professional position. These circumstances forced many talented Hungarian Jews either to convert to Christianity and/or emigrate to other countries (Patai 1996: 240). Moreover, many other Jews changed their German/Jewish names in order to be associated to the Hungarian nation and not the Jewish community (Farkas 2009: 377; Beider 2018: 286).

While strong emigration continued, in the final decades of the nineteenth century the last sizable addition to the Hungarian Jewish community arrived from the neighboring lands of Galicia, nowadays a region divided amongst Ukraine, Poland and Slovakia (Patai 1996: 430). Lajos Venetianer (1922: 464-465) demonstrates that the Jewish population of the counties of Sáros, Szepes, Ung, and Zemplén rose from 1,639 individuals in 1880 to 23,706 in 1910. Many of these "Galicians," as they were called by the Hungarian local Jews, were rapidly assimilated into the Hungarian culture (Patai 1996: 431). The rise of Nazism in Germany and its consequent expansion in Central Europe during the 1930s and early 1940s led to the extermination of approximately two thirds of the Hungarian Jewry. Many of the members of the community suffered death while others never returned to Hungary after their liberation from Nazi concentration camps (Karady 1993: 85-86). 
Ferdinand, Siarl. "An Overview of the Language History of the Hungarian Jewish Community in the Carpathian Basin and Diaspora with a Special Emphasis on Yiddish." Hungarian Cultural Studies. e-Journal of the American Hungarian Educators Association, Volume 13 (2020) DOI: 10.5195/ahea.2020.395

\section{The Languages of the 'Hungarian' Jews}

Many of the names of Jews living in Pannonia and Dacia found on monuments dating from the second and third centuries CE had Latin names; at least one inscription alludes to the Diis Manibus, the Roman gods of death. It can therefore be concluded that these Jews were thoroughly assimilated into Roman culture and most were Latin speakers (Patai 1996: 22). There are, however, other inscriptions in Greek with the phrase borrowed from Deuteronomy 6:4, "God is One" (Schreiber 1983: 21). The first inscriptions in Hebrew appear following the arrival of the Kabars in the eighth and ninth centuries (Rosenhaus 2018: 456). It can be assumed that this community used Hebrew for at least ceremonial reasons (Vachkova 2008: 353; Golden 2007: 146; Schreiber 1983: 77). During the Middle Ages, the Jewish community increased steadily; thanks to the arrival of Jews from different parts of Europe, Yiddish, a Germanic language with significant Semitic, Slavic and Hungarian components (Rothstein 2006: 1203; Rosenhaus 2018: 454), became the most spoken language. Based on the language in which some documents were written and signed, Yiddish was mostly a low/spoken language, in clear contrast to Hebrew, the high/written language (Patai 1996: 111, 207; Bányai 2013: 76-77). By the end of the eighteenth century, many Jews in Western Hungary usually spoke German and/or Western Yiddish; between the Tisza River and the Carpathian Mountains, Eastern Yiddish was spoken, while in Central Hungary, Hungarian was the language used in daily life (Spolsky 2014: 212).

The beginning of the linguistic assimilation of the Jewish community in Hungary can be traced to 1783 with the issue of the Systematica Gentis Judaica Regulatio ['Systematic Regulation of the Jewish Nation'] by the Austrian Emperor, Joseph II (1741-1790). With this law, Jews were ordered to write all documents either in Latin or another local language, mostly German or Hungarian. Although the law permitted the use of books in puro Hebraico ['pure Hebrew' or 'pure Jewish language'], necessary for the performance of religious services, it banned any written form of Yiddish, a language described with the pejorative phrase of Judaico corrupto Idiomate ['corrupt Jewish language'] (Komoróczy 2005). The Austrian Emperor's imposition of German upon Hungary following a decree signed in 1784 changed the language landscape of the Kingdom in an unexpected manner. This decree provoked the awakening of language consciousness among the region's different nationalities, such as the Magyars, Croatians, Slovaks, etc., who demanded the officiality of their languages along with Latin, instead of German (Gal 2011-2: 35; Aspaas \& Kontler 2015: 96). By this time, Yiddish was already immersed in the process of language substitution throughout Europe (Beider 2018: 286). This decline in Yiddish also arrived at the religious domain in Hungary when, in 1830, Yiddish was replaced by German as the language for the sermons at the Cultus Tempel in Pest. At Jewish schools, the most important subjects (namely religious ones) continued to be taught in Yiddish; secular school subjects, however, started to be taught in Hungarian. While the Regulatio was partly responsible for these changes, it is also true that this language shift also reflected the widespread sentiments of many in the Jewish community who desired to be fully integrated into Hungarian society as they viewed themselves as Magyars of Jewish religion/ancestry (Karady 1993: 75; Patai 1996: 244-245, 358). As such, these individuals viewed the acquisition of Hungarian as a means of modernizing the Jewish community (Patai 1996: 245, 308). As a result, by the middle of the nineteenth century, only remnants of Western Yiddish survived in isolated corners of Hungary and Slovakia (Fishman 1991: 83). Mostly due to immigration from Galicia 
Ferdinand, Siarl. "An Overview of the Language History of the Hungarian Jewish Community in the Carpathian Basin and Diaspora with a Special Emphasis on Yiddish." Hungarian Cultural Studies. e-Journal of the American Hungarian Educators Association, Volume 13 (2020) DOI: 10.5195/ahea.2020.395

(Fleischer 2018: 245), Eastern Yiddish, however, saw an increase in speakers for a short period in Hungary.

In any case, by the turn of the twentieth century, the process of adopting the Hungarian language was very advanced throughout Hungary (Vajda 1896: 55; Patai 1996: 283). According to the Census carried out in 1910, 75.7 percent of Hungarian Jews chose to declare themselves as native speakers of Hungarian, a number that neither reflects their actual skills in Hungarian nor the fact that Yiddish was not featured amongst the possible language choices (Patai 1996: 431; Weinreich 2008: 297). Nevertheless, some individuals remained faithful to Yiddish and strove to make it a modern and prestigious language. For example, in 1908 a group of scholars met in Czernowitz (now Chernivtsi, Ukraine) and designated Yiddish as the national language of the Jewish people (Peltz 2010: 140; Goldsmith 1997: 15). This position was ratified on several occasions, such as in 1920 at the conference of Csap (now Chop, in Ukraine), where Yiddish was proclaimed the sole spoken Jewish language (Spolsky 2014: 209).

The Hungarian Jewry's ambivalence towards the Yiddish language was reflected in the Zsidó Lexikon ['Jewish Encyclopedia'] published in 1929. The entry regarding Yiddish does not appear under Jiddis ['Yiddish'], but rather as Jargon (preserving the French spelling). The article starts by introducing the term as usually a "hibás ['incorrect'], helytelen ['inappropriate'] or romlott ['corrupt'] language," a view which was most probably shared by many assimilationist Jews. In its continuation, however, the article provides a different and slightly more positive perspective by linking the term 'jargon' to the dialects of certain peoples, constructed languages and mixtures of different languages. Only later does it mention that this [Galician] "jargon" is "nowadays called Yiddish." The article reiterates the idea propagated by the sixteenth century scholar, Elia Levita, who stated that Yiddish is the language of the German Jews (Italics added) who migrated to Poland, Lithuania and Russia. In fact, the only reference to Hungary is found in the last line, in which the author mentions József Holder as the only Yiddish writer of Hungary (Ujvári 1929: 406; Baumgarten 2005: 165).

Despite these timid intents at clearing the perception of the language, by the 1930s the employment of Yiddish was almost exclusively limited to the ultra-orthodox communities of "Galician" Jews (Spolsky 2014: 212). This does not mean that there were very few speakers; in 1931, roughly 270,000 individuals out of approximately one million used Yiddish. Instead, it can be said that Yiddish had ceased to be the language of the Hungarian Jews (Birnbaum 1979: 41). The wave of totalitarianism that flooded Europe especially during the 1930s and 1940s also affected Hungarian Jews. During this period, three national anti-Jewish laws were passed in 1938, 1939 and 1941 (Cole 1999: 24). Whenever there was an opportunity to do so, a relatively high percentage of the people affected by these decrees migrated to countries where they were better accepted (Patai 1996: 274, 506, 530, 541). The subsequent Holocaust brought about the annihilation of approximately two thirds of Hungary's Jewish population and almost the total extinction of its Yiddish-speaking community. The post-Holocaust era saw an almost continuous depletion in the number of Hungarian Jews living in the Carpathian Basin, a circumstance that the factors of low birth rate, emigration to Israel and other countries and assimilation into the Magyar general population contributed to (Patai 1996: 506, 617). 


\section{Yiddish Among the Hungarian Jewry Today}

In order to attain an accurate and updated perception of the state of Yiddish usage within the Hungarian Jewish community found both in the Carpathian Basin and abroad, several approached were used for this study. Other than documentary investigation, a bilingual Hungarian/English questionnaire consisting of thirty questions was specially developed (See Appendix for the English version). The data were analyzed by calculating percentages based on the participants' answers, usually marked on a five-grade Likert scale. Additionally, a series of unstructured interviews were conducted with Dr. Noémi Vanderstein and Dr. Balázs Fényes (a Yiddish speaker himself) to gather their viewpoints regarding the survey findings. These fruitful and enlightening conversations provided many additional details about the state and evolution of the language, particularly in the Hungarian-speaking areas of the Carpathian Basin. Their extensive experience and knowledge of Jewish languages (and their related identities) proved invaluable. All answers were recorded in spoken form, to which narrative analysis was applied. Both in Hungary as well as in countries with considerable Hungarian minorities, several Hungarian cultural associations (not necessarily Jewish in origin), Jewish associations, synagogues and individuals were contacted via their public addresses. These institutions, including the Federation of Hungarian Jewish Communities (MAZSIHISZ), the American Hungarian Educators Association (AHEA) and the Jewish Theological Seminary - University of Jewish Studies in Budapest, were thoroughly informed about the aim of the research. Individuals who volunteered to fill out the questionnaires could do so anonymously via Sogo Survey (www.sogosurvey.com) and Survey Planet (surveyplanet.com). In addition, twenty paper-based questionnaires were also filled out by participants in the county of Csongrád, located in Southern Hungary. All the organizations and individuals were contacted, and the questionnaires were distributed during spring and summer of 2016. Both the organizations and individuals were thoroughly informed of the purpose of this study; volunteers were told that no financial compensation would be offered for their participation. Furthermore, the participants were notified about their right to withdraw at any moment, as well as the anonymous nature of their involvement.

The final results were based on one hundred-thirty valid answers from individuals aged between the ages of 23 and 88. Seventy-four participants were residents of countries in the Carpathian Basin: 67 live in Hungary and seven in Romania, Serbia and Croatia. The remaining 56 participants were located in different regions and countries, such as Western Europe, North America and Israel. The percentage of participants living in each area must not be understood as the actual rate of distribution of the Hungarian Jewish community in the world as this percentage remains undetermined. Moreover, due to several other factors, such as the limited number of participants and the impossibility of reaching every Hungarian Jewish community, the results may be viewed as a pilot study of the situation of the Yiddish language rather than a detailed description of it.

\section{Current Usage and Attitudes Towards Yiddish by the Hungarian Jewry}

The end of the communist era brought about a revival of the Jewish culture in Hungary. Since the 1990s, several works written by Yiddish authors have been translated into Hungarian. The presence of Yiddish is further supported by Jewish culture festivals, showings of old Yiddish films in cinemas. Yiddish musical ensembles also hold performances, some of which 
Ferdinand, Siarl. "An Overview of the Language History of the Hungarian Jewish Community in the Carpathian Basin and Diaspora with a Special Emphasis on Yiddish." Hungarian Cultural Studies. e-Journal of the American Hungarian Educators Association, Volume 13 (2020) DOI: 10.5195/ahea.2020.395

have attained international success, such as the Budapest Klezmer Band (Patai 1996: 643). In spite of these efforts, Yiddish is still an invisible language for most people, including many Jews. Although Yiddish is studied in at least two universities (namely Eötvös Loránd University (ELTE) and the Budapest University of Jewish Studies), during the preparation of this research, no evidence of Yiddish being regularly taught in any kindergarten, primary or secondary school was found. Moreover, the use of the language in Hungary is almost non-existent on the Internet since no website with a Yiddish version of the information offered in Hungarian and/or other languages of the Carpathian Basin was located. Nevertheless, many of these websites often have at least some content in English and sometimes in Hebrew. According to the Hungarian Census, it can be said that all the Jews living in Hungary are proficient in Hungarian. Many of those living in other countries of the Carpathian Basin are speakers of the local languages and have quite often maintained Hungarian (Hungarian Central Statistical Office 2014a). This finding is reaffirmed by the responses given to Question 8 in the survey prepared for this investigation as ninety percent of the respondents declared that Hungarian is their main language. All answers given to Question 9 stated that participants have a high or very high proficiency in Hungarian.

However, the question of what remnants of Yiddish may be found among the Jewish population living in Hungary has not been adequately examined. In 1991, Fishman provided some unrealistic figures suggesting that in 1980 there were 24,000 native speakers of Yiddish, totaling 30 percent of the 80,000 Jews living in Hungary (Fishman 1991: 340). Despite this estimate, the Hungarian Census 2011 did not register any Yiddish speakers either among the 10,965 individuals who declared themselves Jewish by religion or the remaining Jews who do not practice Judaism (Hungarian Central Statistical Office 2014a; 2014b: 150). Similarly, there seems to be a relatively extensive idea amongst non-Jews that Hungarian Jews speak Yiddish at home and Hungarian in public, a view that probably owes much to the lingering stereotypes that surrounded immigrant Galician Jews (Patai 1996: 498). Nearly three decades after the data provided by Fishman (1991), the time has come to gain a new understanding on language distribution, maintenance and/or transmission as regards Yiddish usage amongst Hungarian Jews.

To acquire the most accurate and recent insight into this topic, Questions 9, 10, 11 and 12 probed how well the respondents can speak, understand, write and read Yiddish. Of all the participants living in any of the countries in the Carpathian Basin, those with any skills in Yiddish comprise a small minority totaling roughly nine percent of the total. However, those who also state that they can understand spoken Yiddish only comprise three percent (Graphs 1A and 1B). The same pattern is repeated in written Yiddish. Although 11 percent state that they can write some Yiddish, only three percent admit to being able to understand books or newspapers (Graphs 1C and 1D). This may suggest that most of those who declare any skills in Yiddish may have a very superficial knowledge of the language, which was probably transmitted within the family, and may not be active users of it beyond knowing a few words that have already become embedded into Hungarian. According to Dr. Balázs Fényes, most of those individuals living in Hungary who possess an intermediate or high level of competency in Yiddish use Eastern Yiddish, a circumstance that very often indicates a language learnt in schools and universities instead of one transmitted from parents to children (Horsby 2015: 86). Western Yiddish, once the majority dialect spoken in the cities and towns west of the Tisza River, may be virtually dead in Hungary. In fact, for the Jews living in Hungary, the question of language has ceased to be an 
Ferdinand, Siarl. "An Overview of the Language History of the Hungarian Jewish Community in the Carpathian Basin and Diaspora with a Special Emphasis on Yiddish." Hungarian Cultural Studies. e-Journal of the American Hungarian Educators Association, Volume 13 (2020) DOI: 10.5195/ahea.2020.395

issue. As was commented by Dr Vanderstein, this may have been important about a hundred years ago, but nowadays, only some people take it seriously while for others it has no relevance. In fact, in contrast to what happens in some nations, for most Jews language is only a small percentage of their identity along with religion, clothes, history, folklore, etc. (Susser 2002: 222). In fact, authors such as Shulamit Volkov have defined Judaism as a multifaceted cultural system (Volkov 2003: 214, 216).

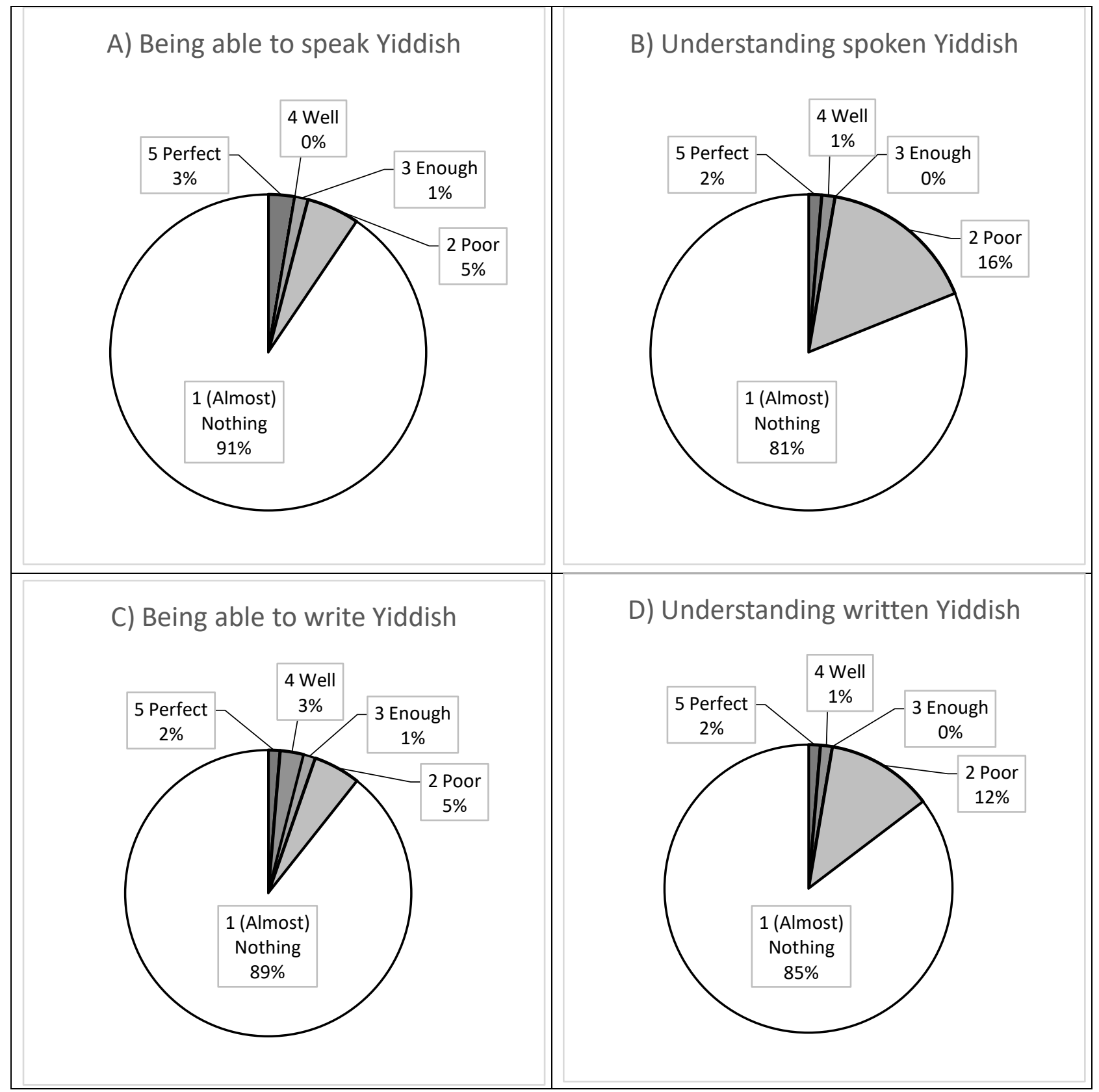

Graph 1. Skills in Yiddish (Responses from 74 participants living in Hungary and the rest of the Carpathian Basin) 
The results concerning the language which plays the main role in the speakers' lives or with which they feel more comfortable speaking demonstrate an even weaker presence of Yiddish. Participants almost unanimously state that their main language is either Hungarian or any of the other local languages in the region. Only one participant considered Yiddish his/her main language (Graph 2A). Moreover, all respondents stated that they have perfect or good command of Hungarian (Graph 2B).

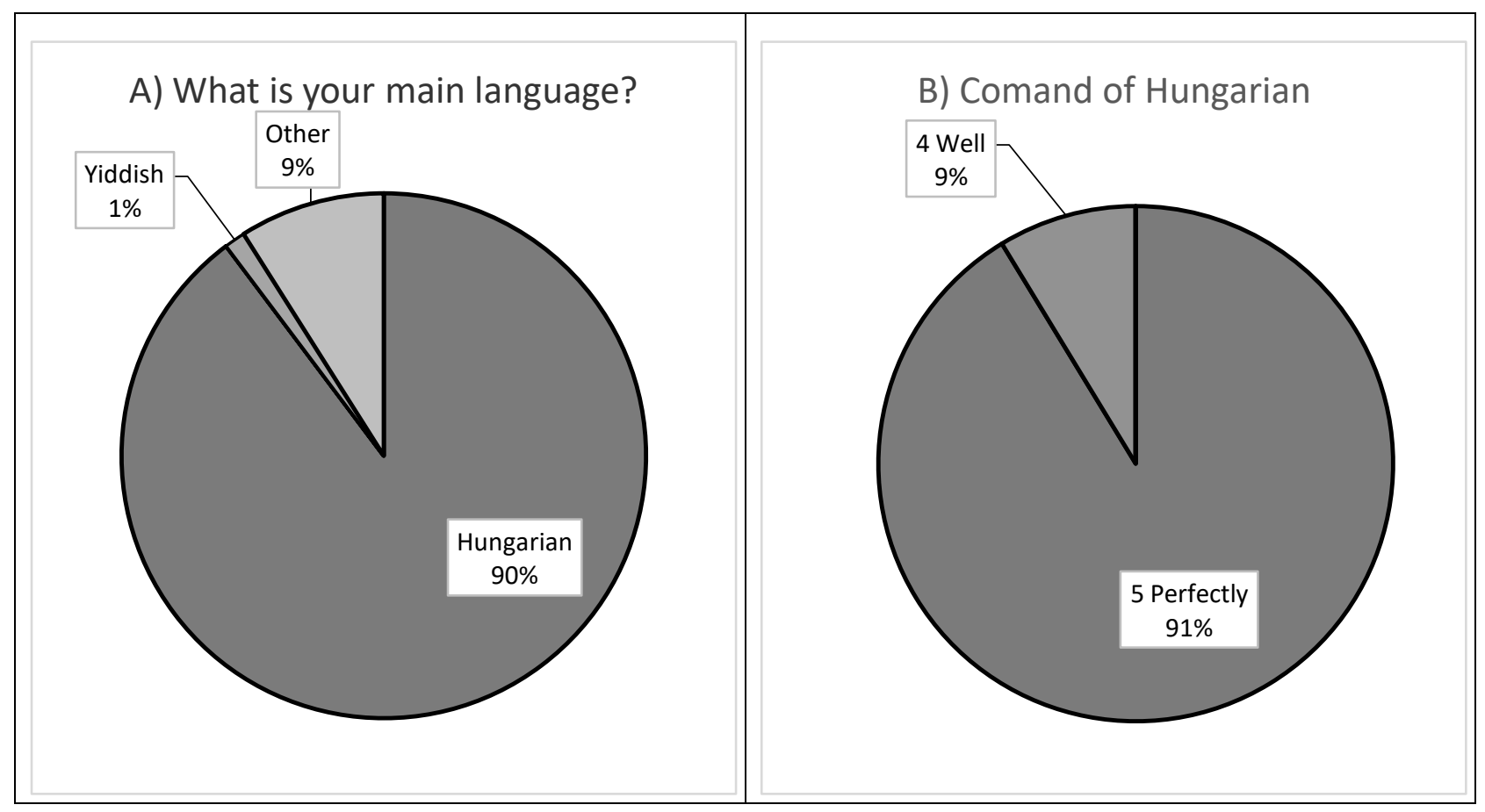

Graph 2. Main language and competence in Hungarian among respondents located in the Carpathian Basin (74 individuals)

Hungary's Jewry has suffered diasporic tendencies for centuries. This trend has sometimes been attenuated by cycles of high birth rate amongst its members or the immigration of Jews from other countries who were usually fleeing persecution (Spolsky 2014: 171-173). One of the most important exoduses of Jews from Hungary occurred during the four decades of 1871-1910, when no fewer than 175,000 Jews (many of whom were Yiddish speakers) emigrated from the northeastern counties of the Hungarian Crown (Patai 1996: 430-431). This wave of migration led to the establishment of Hungarian Jewish communities in different countries, particularly in North America. The 1940s followed by the 1956 Hungarian Revolution marked two other periods when thousands of individuals emigrated from Hungary. Those communities, including Modern Orthodox, Reform Jews, Conservative Jews, Ultra-Orthodox Jews, and nonobservant Jews, had and have preserved different views on their native, ethnic and host languages.

One of the groups who would (and still) play a very important role in the use and preservation of Yiddish in America are the Ultra-Orthodox Jews, a large percentage of whom 
Ferdinand, Siarl. "An Overview of the Language History of the Hungarian Jewish Community in the Carpathian Basin and Diaspora with a Special Emphasis on Yiddish." Hungarian Cultural Studies. e-Journal of the American Hungarian Educators Association, Volume 13 (2020) DOI: 10.5195/ahea.2020.395

(particularly among the Hasidim) are post-World War II immigrants and Holocaust survivors from Hungary. (In this case, Hungary includes Transylvania, nowadays in Romania, and Kárpátalja or Carpathian Ruthenia, currently a Ukrainian oblast). For them, Yiddish was and still is not only a tool for gaining access to advanced traditional Jewish studies, but also a means of separation from the non-Jewish and non-religious aspects of American-Jewish life or American life in general (Fishman 1991: 131, 133). One of the most notable dialects of this category, Haredi-Satmar Yiddish, has its origins in the Jewish community of the city of Szatmárnémeti (now Satu-Mare in Romania), whose surviving members arrived in the United States mostly after 1945 (Krogh 2018: 5-6). Although the language spoken by the Haredi-Satmar Jews exhibits certain orthographic, morphosyntactic, and lexical differences compared to the language employed by non-Haredi speakers, it is perfectly comprehensible for Yiddish speakers of other groups (Kahn 2016: 653-654). Moreover, this Hungarian-Yiddish dialect has become so influential that many non-Hungarian communities have adopted its traits in their Polish-Yiddish or Lithuanian-Yiddish dialects both in the United States and abroad (Sadock \& Masor 2018: 108). As reported by Dovid Katz (1988: 385), whether a native language or a language learnt later in life, Yiddish has enjoyed excellent health among Jews from more or less isolated Hasidic communities during the last decades. Such is still the case in the village of Kiryas Joel, New York, where ninety percent of its inhabitants (Hungarian Jews being the most prominent group) were Yiddish speakers in 2000 (Modern Language Association 2011; Krogh 2018: 38). One example that illustrates the vitality of Yiddish among these Haredi communities is the fact that children are taught in Yiddish-language medium kindergarten. In the primary school, boys are taught that maintaining Yiddish at home is one of their gendered responsibilities to counteract the introduction of English in the family life by their mothers (Fader 2007: 12).

The use of Yiddish in religious communities is not restricted to a few Ultra-Orthodox groups. Other Jewish groups also respect and use Yiddish to a certain extent. Even some nonJewish denominations, such as the Glendale congregation of Jehovah's Witnesses in New York, have services in Yiddish (JW.org 2019). While these religious communities are not strictly Hungarian, the presence of Hungarian Jews cannot be removed from consideration. In any case, since Hungary lost most of its Yiddish speakers during the nineteenth century, it is safe to assume that a high percentage of observant Hungarian Jews would not use Yiddish in their diasporic communities. Apparently, a similar position may have been adopted by most secularist Jews, which has put Yiddish in serious jeopardy since some researchers such as Yaron Matras (2010) state that in the secular sector, Yiddish is a highly endangered language and has not been passed on to children for decades, making of it a post-vernacular or symbolic language among the Ashkenazi Jews who do not speak it fluently (Sallabank 2013; Shandler 2006). An example of this situation can be seen in the use of some Yiddish words and expressions embedded in English amongst many of the Ashkenazi Jews living in the United States (Benor 2011: 152). Although not good, this situation does not imply that Yiddish is already a dead language within the non-observant society. In some locations with large Ashkenazi populations (including many Hungarians), such as New York, Antwerp or Warsaw, there are Yiddish-language theatres, schools, newspapers/magazines, radio stations and other organizations that promote the language. Moreover, as was confirmed by Dr. Fényes, a growing interest in Yiddish is being expressed by both heritage learners as well as non-Jewish individuals who subsequently study the language in universities and schools worldwide (Kahn 2016: 653-654). 
Ferdinand, Siarl. "An Overview of the Language History of the Hungarian Jewish Community in the Carpathian Basin and Diaspora with a Special Emphasis on Yiddish." Hungarian Cultural Studies. e-Journal of the American Hungarian Educators Association, Volume 13 (2020) DOI: 10.5195/ahea.2020.395

The results of the small survey carried out among 56 Hungarian Jewish individuals living in different countries display only slightly better results compared to the ones obtained in the Carpathian Basin. Most of the respondents (almost 80 percent) did not declare any skill in Yiddish. However, eight percent state that they can speak Yiddish either perfectly or at least well while 10 percent claimed they can understand in the same levels (Graphs 3A and 3B). Similar to the results reached in the Carpathian Basin, written skills in Yiddish were much more limited, with only four and six percent saying they are able to write and understand written Yiddish either perfectly or well (see Graphs 3C and 3D).

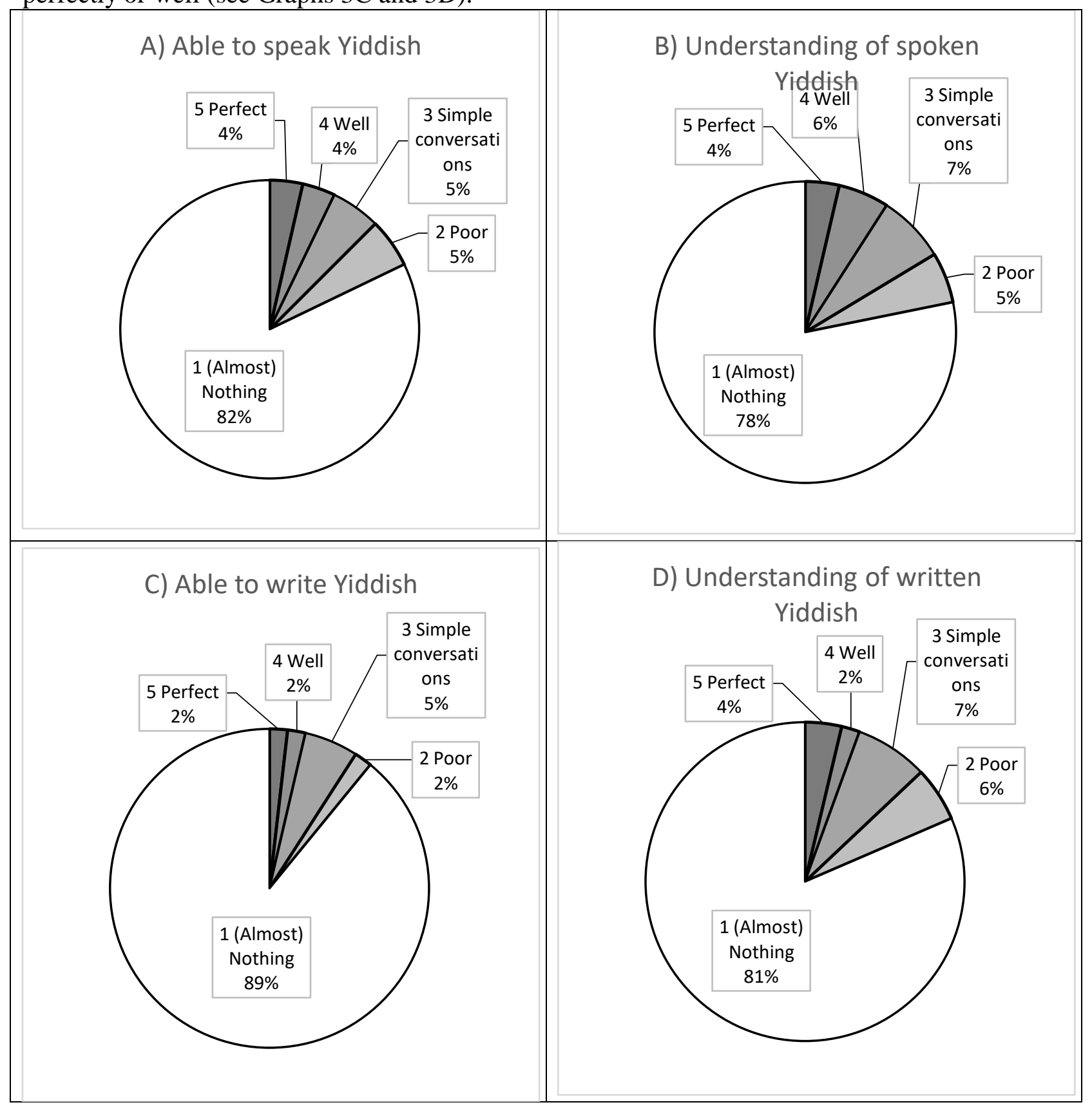

Graph 3. Skills in Yiddish? (Responses from 56 participants living in the diaspora) 
The answers given in connection to the dominant language and level of competency in Hungarian amongst individuals living in the diaspora revealed some interesting facts. On the one hand, most participants report Hungarian (or any of the languages in the host country, including Hebrew in Israel) as their main language. Only three percent state that Yiddish occupies this place in their lives (Graph 4A). Moreover, an overwhelming majority of the participants state that they can speak Hungarian perfectly or at least well, which seems to make this language the actual heritage language of the group (Graph 4B).

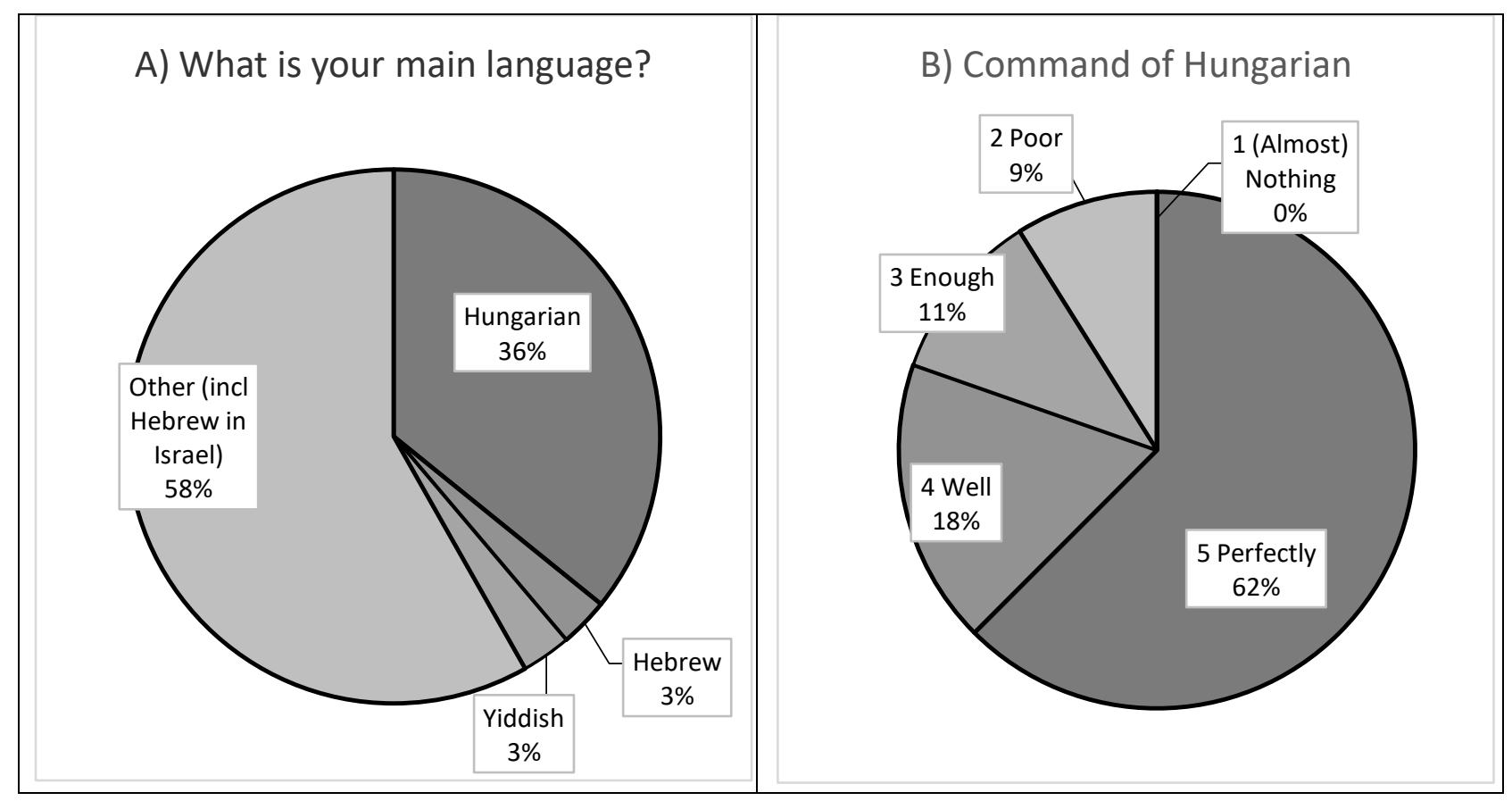

Graph 4. Main language and competency in Hungarian amongst respondents located in countries outside of the Carpathian Basin (56 individuals)

\section{Conclusion}

This paper has demonstrated how the desire to be integrated into society and the need to preserve their strong cultural identity have led the Hungarian Jewish community to adopt several languages throughout history. From Latin (and probably Greek) during the centuries preceding the arrival of the Magyars or the Honfoglalás period, Jews have switched to several languages including Yiddish, German and Hungarian. After the emergence of nationalism(s) accompanied by the theoretical adscription of a language to every "nation," speakers, scholars, religious and political leaders experimented with replacing Yiddish for a number of languages, notably modern Hebrew, English, standard German and French (Spolsky 2014: 255; Matras 2010; Myhill 2004: 70). Yet another group (including the scholars who participated in Czernowitz in 1908) called for Yiddish to be the national language of the Jewish people (Goldsmith 1997: 15). By that time, due to their desire to be an active part of Hungarian society, most Hungarian Jews had already switched to Hungarian or German; only a minority preserved Yiddish or chose other local languages (Patai 1996: 431). The language switch from Yiddish to Hungarian and other languages was not complete. 
As this paper has demonstrated, today the active knowledge of Yiddish has been reduced to encompass a relatively small minority. According to the results obtained in this investigation, most respondents from the Carpathian Basin state that Hungarian is their main language, while some individuals are speakers of Serbian, Romanian, Croatian or Slovak together with Hungarian. Still, approximately ten percent of the survey's participants declared that they can speak at least some Yiddish. Most of these speakers are second-language speakers, meaning that they have learnt Yiddish at school, university or by themselves, not from their families. Most Hungarian Jews living in diaspora communities stated that their main language is either Hungarian or the language of their host country. Some have Yiddish and a few who do not live in Israel declared Hebrew to be their main language. According to this pilot study, although the percentage of Yiddish speakers found in diaspora communities is higher than in the Carpathian Basin, it still does not reach twenty percent. These data may therefore reignite the old debate surrounding the possible death of Yiddish. At this juncture, it is necessary to remember that Hungarian Jews are in a peculiar situation. Although many may come from families who used to contain Yiddish speakers, the language had already been replaced (mostly by Hungarian or German) for at least one hundred years. For these individuals, Yiddish may resemble what Latin comprises for Italians: namely, a part of their cultural heritage but not their language anymore. Yiddish has therefore lost most of its protagonist role, becoming marginal for most Hungarian Jews (Rosen 2014: 45). In some locations where there are noticeable concentrations of Yiddish speaking Ashkenazim, Yiddish-language schools, newspapers and theaters are also present. Moreover, there is a growing interest in Yiddish amongst both heritage learners as well as nonJewish individuals who study the language in universities and schools worldwide.

Although this research has reached its aims, the results of this pilot study must be interpreted with caution as a number of limitations should be borne in mind. The most notable one concerns the lack of consensus regarding the number of members of the Hungarian Jewry, a missing piece of data that makes it impossible to set a minimum sample of participants for the survey. Moreover, the community's dissemination throughout the entire world means that reaching all (or most) of its members is impossible, including individuals of the influential Yiddish speaking Haredi-Satmar community. For these reasons, this research was only conducted on a small segment of the population belonging to this group. At the same time, interviews made with specialists and the comments made by some participants provided additional information about the findings, thereby mitigating this limitation. The language history of the Hungarian Jewry is an interesting topic that has only been studied marginally, usually as a part of the general Jewish history. This topic is not only fascinating per se, but also provides an indication of how minorities evolve and abandon some ethnic or cultural features in order to survive, adapt to new circumstances, yet still maintain their identity. Future research may broaden this topic by also studying similar phenomena amongst other Jewish groups such as the Sephardim, Ethiopian Jews, Yemeni Jews, etc. located in different contexts. Studies of these Jewish communities may uncover either similar sociolinguistic trends or variables which led these communities to different situations. This will not only increase our understanding of the present, but also enable an effective management of the future of Jewish languages. 
Ferdinand, Siarl. "An Overview of the Language History of the Hungarian Jewish Community in the Carpathian Basin and Diaspora with a Special Emphasis on Yiddish." Hungarian Cultural Studies. e-Journal of the American Hungarian Educators Association, Volume 13 (2020) DOI: 10.5195/ahea.2020.395

\section{Works Cited}

Aspaas, Per Pippin \& Kontler, László. 2015. "Before and After 1773: Central European Jesuits, the Politics of Language and Discourses of Identity in the Late Eighteenth Century Habsburg Monarchy.” In Latin at the Crossroads of Identity. Eds. Gábor Almási and Lav Šubarić. Leiden: Brill. 95-118.

Bányai, Viktória. 2013. "The Hebrew Language as a Means of Forging National Unity: Ideologies Related to the Hebrew Language at the Beginning of the 19th and the 20th Centuries". In Between Minority and Majority. Hungarian and Jewish/Israeli ethnical and cultural experiences in recent centuries. Eds Pál Hatos \& Attila Novák. Budapest: Balassi Institute. 74-85.

Baumgarten, Jean. 2005. Introduction to Old Yiddish Literature. trans. Jerold C. Frakes. Oxford: Oxford UP.

Beider, Alexander. 2018. "Yiddish in Eastern Europe". In Languages in Jewish Communities, Past and Present. Eds. Benjamin Hary \& Sarah Bunin Benor. Boston: De Gruyter. 276312.

Benor, Sarah Bunin. 2011. Mensch, bentsh, and balagan: Variation in the American Jewish linguistic repertoire. Language \& Communication, 31:141-154.

Birnbaum, Solomon A. 1979. Yiddish: A Survey and a Grammar. Toronto: Toronto UP.

Carmilly-Weinberger, Moshe. 1995. A Zsidóság története Erdélyben ['History of the Jews in Transylvania']. Budapest: MTA-Judaisztika Kutatócsoport.

Cole, Tim J. 1999. Constructing the 'Jew', Writing the Holocaust: Hungary 1920-45, Patterns of Prejudice, 33.3: 19-27, DOI: 10.1080/003132299128810605

Della Pergola, Sergio (ed.). 2010. World Jewish Population, 2010. Stors, CT: North American Jewish Data Bank.

Fader, Ayala. 2007. Reclaiming Sacred Sparks: Linguistic Syncretism and Gendered Language Shift among Hasidic Jews in New York. Journal of Linguistic Anthropology, 17.1:1-22.

Farkas, Tamás. 2009. Jewish Surname Changes in Hungary (19th-20th century). Proceedings of the 23rd International Congress of Onomastic Sciences. Toronto, Canada: York University. 375-384. Accessed 01 June 2019.

https://yorkspace.library.yorku.ca/xmlui/handle/10315/3968

Fishman, Joshua A. 1991. Yiddish Turning to Life. Amsterdam: John Benjamins.

Fleischer, Jürg. 2018. "Western Yiddish and Judeo-German". In Languages in Jewish Communities, Past and Present. Eds. Benjamin Hary \& Sarah Bunin Benor. Boston: De Gruyter. 239-275.

Gal, Susan. 2011-2. Polyglot nationalism. Alternative perspectives on language in 19th century Hungary. Langage et Société, 136:31-54.

Golden, Peter B. 2007. "The Conversion of the Khazars to Judaism". In The World of the Khazars. Eds Peter B. Golden, Haggai Ben-Shammai \& András Roná-Tas. Leiden \& Boston: Brill. 123-162.

Goldsmith, Emanuel S. 1997. Modern Yiddish Culture: The Story of the Yiddish Language Movement. New York: Fordham UP.

Haraszti, György. 1997. "The Return of the Jews to Hungary in the XVIII Century". Rivista di Studi Ungheresi, 12:37-53. 
Ferdinand, Siarl. "An Overview of the Language History of the Hungarian Jewish Community in the Carpathian Basin and Diaspora with a Special Emphasis on Yiddish." Hungarian Cultural Studies. e-Journal of the American Hungarian Educators Association, Volume 13 (2020) DOI: 10.5195/ahea.2020.395

Horsby, Michael. 2015. Revitalizing Minority Languages. New Speakers of Breton, Yiddish and Lemko. New York: Palgrave Macmillan.

Hungarian Central Statistical Office. 2014a. 2011. A népesség száma és megoszlása nyelvismeret szerint ['Number and Distribution of Population by Language Proficiency']. Accessed 08 February 2019. www.ksh.hu/nepszamlalas/docs/tablak/demografia/04_01_01_18.xls

Hungarian Central Statistical Office. 2014b. 2011. Évi Népszámlálás. 10. Vallás, felekezet ['Annual Census. 10. Religion, Confession']. Budapest: Központi Statisztikai Hivatal.

JW.org. 2019. Find a Meeting. Accessed 16 September 2019 https://apps.jw.org/ui/E/meetingsearch.html\#/dashboard/Y/New\%20York,\%20NY,\%20USA/40.712775,-74.005973/

Kahn, Lily 2016. Yiddish. In Handbook of Jewish Languages. Eds. Lily Kahn \& Aaron D. Rubin.Leiden: Brill.

Karady, Victor.1993. Antisemitism in twentieth-century Hungary: A socio-historical overview, Patterns of Prejudice, 27.1:71-92, DOI:10.1080/0031322X.1993.9970098

Katz, Dovid. (ed.). 1988. Words on Fire. The Unfinished Story of Yiddish. New York: Basic Books.

Komoróczy, Géza. 2005. II. József király (1765/1780-1790), német-római császár "Systematica gentis Judaicae regulatio" (Az úgynevezett Türelmi rendelet) ['King Joseph II (1765/17801790) German-Roman Emperor "Systematica gentis Judaicae regulatio" (The so-called Grace Regulation)']. In Források és dokumentumok a zsidók történetéhez.

Magyarországon. Szöveggyüjtemény ['Sources and Documents of the Jewish History in Hungary’]. Ed. Géza Komoróczy. Budapest: MTA Judaisztikai Kutatóközpont. Accessed 18 July 2019 http://www.hebraisztika.hu/szovgyujt/KG_chrest_074.pdf

Krogh, Steffen. 2018. How Yiddish is Haredi Satmar Yiddish? Journal of Jewish Languages, 6:5-42.

Matras, Yaron. 2010. "Yiddish (East)." Archive of Endangered and Smaller Languages. Accessed 14 February 2019. http://languagecontact.humanities.manchester.ac.uk/ELA/languages/Yiddish.html

Modern Language Association. 2011. MLA Language Map Data Center. Accessed 15 February 2019. https://apps.mla.org/cgi-shl/docstudio/docs.pl?map_data_results

Myhill, John. 2004. Language in Jewish Society: Towards a New Understanding. Clevedon: Multilingual Matters.

Patai, Raphael. 1996. The Jews of Hungary. History, Culture, Psychology. Detroit: Wayne State UP.

Peltz, Rakhmiel. 2010. The Success of the Czernowitz Yiddish Conference: Setting the Agenda for Yiddish Language Planning in the Twentieth Century. In Czernowitz at 100. The First Yiddish Language Conference in Historical Perspective. Eds. Kálmán Weiser \& Joshua A. Fogel. Lanham: Lexinton Books.

Rosen, Ilana. 2014. "Fragments of a Hungarian Past in the Literature of 1.5 and SecondGeneration Austro-Hungarian Immigrants in Israel." Hungarian Cultural Studies, 7:41-53. DOI: $10.5195 /$ ahea.2014.138

Rosenhaus, Judith. 2018. "Jewish Hungarian in Hungary and Israel”. In Languages in Jewish Communities, Past and Present. Eds. Benjamin Hary \& Sarah Bunin Benor. Boston: De Gruyter. 453-471. 
Rothstein, Robert A. 2006. "Yiddish." In Concise Encyclopedia of Languages of the World. Eds. Keith Brown \& Sarah Ogilvie. Amsterdam: Elsevier. 1203-1206.

Sadock, Benjamin \& Masor, Alyssa. 2018. "Bobover Yiddish: "Polish" or "Hungarian?". Journal of Jewish Languages, 6:89-110.

Sallabank, Julia. 2013. Attitudes to Endangered Languages. Identities and Policies. Cambridge: Cambridge UP.

Schreiber, Sándor. 1983. Jewish Inscriptions in Hungary: From the 3rd Century to 1686. Leiden: Brill.

Shandler, Jeffrey. 2006. Adventures in Yiddishland. Berkeley: University of California Press.

Simons, Gary F. \& Charles D. Fennig (eds.). 2018. Ethnologue: Languages of the World, Twenty-first edition. Dallas, Texas: SIL International. Accessed 05 February 2019 http://www.ethnologue.com.

Spolsky, Bernard. 2014. The Languages of the Jews: A Sociolinguistic History. Cambridge: Cambridge UP.

Susser, Bernard. 2002. "The Ideology of Affliction. Reconsidering the Adversity Thesis." Diasporas and Exiles. Varieties of Jewish Identity. Ed. Howard Wettstein. Berkeley: University of California Press. 221-233.

Ujvári, Péter (ed.). 1929. Zsidó Lexikon. Budapest: Pallas.

Vachkova, Veselina. 2008. "Danube Bulgaria and Khazaria As Parts Of The Byzantine Oikoumene". In The Other Europe in the Middle Ages: Avars, Bulgars, Khazars, and Cumans. Eds. Florin Curta and Roman Kovalev. Leiden: Brill. 339-362.

Vajda, Béla. 1896. A Zsidók torténete Abonyban és Vidékén. Budapest: Czettel és Deutsch-Féle Muintézet Nyomása.

Venetianer, Lajos.1922. A Magyar Zsidóság Torténete. A Honfoglalástól a Világháború Kitoréséig. Budapest: Fovárosi Nyomda Részvénytársaság.

Volkov, Shulamit. 2003. Inventing Tradition. On the Formation of Modern Jewish Culture. Jewish Studies. III Yearbook (2002-2003). Budapest: Central European University. 211227. Accessed 02 June 2019 http://jewishstudies.ceu.edu/iii-yearbook-2002-2003

Weinreich, Max. 2008. History of the Yiddish Language. Volume 1. New Haven: Yale UP.

\section{Appendix: Questionnaire (English version)}

Sec. 1 - General Data

1) Are you of Jewish origin?

Yes / No

2) Have you got Hungarian origin?

Yes / No

3) How old are you?

4) What is your gender?

Man / Woman 
5) Where do you live most of the time?

In Hungary

Other Hungarian speaking areas in the Carpathian Basin (Transylvania, Voivodina, etc.) Abroad (Where?)

6) Do you participate in Jewish religious ceremonies?

Yes, regularly

Yes, often

Sometimes

Seldom (such as weddings)

Never

7) Do you participate in Jewish cultural (non-religious) events?

Yes, regularly

Yes, often

Sometimes

Seldom (such as weddings)

Never

Sec. 2 - Language Knowledge

8) What is your main language?

Hungarian

Hebrew

Yiddish

Other (please specify)

9) How well can you speak... Hungarian/Yiddish?

Very well (formal and informal)

I speak fluently

I can deal with most situations

Only short conversations

Nothing or only a few words

10) How well can you understand TV, radio and conversations in Hungarian/Yiddish?

Everything

Almost everything

Main points

Some ideas

Nothing or only a few words

11) How well can you write Hungarian/Yiddish?

[Almost] perfectly

Well

Enough

Not very well

Nothing 
12) How well can you understand newspapers, books, and publications in Hungarian/Yiddish?

Everything

Almost everything

Main points

Some ideas

Nothing or only a few words

Sec. 3 - Language Use

13) What is your main language?

Hungarian

Hebrew

Yiddish

Other

14) What language do/did you mainly use at home as a child?

15) What language do/did mainly use with your siblings?

16) What language do/did mainly use with your husband, wife, partner?

17) What language do/did mainly use with your children? 